\title{
Service Delivery in Local Government through Socio-Economic Programmes: Successes and Failures of the Comprehensive Rural Development Programme (CRDP)
}

\author{
Ntwanano Mathebula \\ Junior Lecturer \\ Department of Public Administration, University of Limpopo \\ Ntwanano.Mathebula@ul.ac.za
}

Doi:10.5901/mjss.2014.v5n20p132

\begin{abstract}
The purpose of this article is to reflect on the successes and failures confronting the Greater Giyani Municipality in terms of service delivery through the Comprehensive Rural Development Programme (CRDP) implemented in Muyexe community, Limpopo Province (South Africa). The Constitution of the Republic of South Africa (1996) defines service delivery as the provision of sustainable services by the municipality to communities. Post-apartheid South African municipalities are still confronted with service delivery backlogs, 20 years in to the democratic dispensation. The recipients of municipal services continue to be frustrated by the poor quality and the frequency in which services are delivered to them by the municipality. This provision of goods and services denotes that particular functions must be performed by the municipality. CRDP has emerged from the first two pilot engagements in Riemvasmaak in the Northern Cape, and Muyexe in Giyani in Limpopo Province as part of presidential designated projects. This paper is an empirical study that followed both the qualitative and quantitative methodologies. The data collection instruments used for this study are open-ended questionnaires, unstructured interviews and a number of site visits. The paper argues that the CRDP has inadequately satisfied the intended objectives in the Muyexe Pilot Project. Intended beneficiaries of the programme from the Muyexe community exposed many of the failures of the programme by frustrations about the programme implemented in their community. In concluding this article provide recommendations on how future similar programmes implemented elsewhere at South African municipalities can satisfy the objectives they are originally intended for.
\end{abstract}

Keywords: CRDP, Service delivery, municipalities, South Africa

\section{Introduction}

Post-apartheid South Africa is confronted with major challenges in ensuring that municipalities provide optimum and specialised services to their citizens. The provision of services denotes that specific functions must be executed by municipalities and other sector departments in terms relevant legislative mandates (Nkuna \& Nemutanzhela, 2012). Service delivery challenges that exist within South African municipalities are rooted upon the failure to implement socioeconomic programmes particularly in local government (Vatala, 2005; Patterson, 2008; Mbazira, 2013). Socio-economic programmes are directed at addressing service delivery challenges within the local sphere of government. The CRDP as a socio-economic programme aimed at enhancing service delivery in rural communities was approved by the South African cabinet in 2009. According to the Department of Rural Development and Land Reform (DRDLR) (2009), the programme was launched to redress service delivery injustices and inequalities of the apartheid era, particularly in rural areas. CRDP arises from the fact that an estimated 21 million rural South Africans do not have access to basic services such as housing, clean water, electricity, and food security (StatsSA, 2001). Section 27 of the Constitution of the Republic of South Africa (1996) gives rights to health care, food, water and food security. It was from this constitutional pledge that the CRDP was promulgated. By October 2011, the CRDP was being implemented at 65 sites across the country. CRDP has emerged from the first two pilot engagements in Riemvasmaak, and Muyexe Village in Giyani, Limpopo Province as models for the new intervention. The Greater Giyani municipality faces challenges in accomplishing the strategic objectives of the CRDP implemented at Muyexe village in 2009. The inability to implement the strategic objectives of the CRDP presages that service delivery in South Africa, 20 years in to democracy is meticulously hampered. It is against this background that this paper reports on successes and failures confronting the Greater Giyani municipality to effectively deliver services through the CRDP. 


\section{Service Delivery in South African Municipalities}

The beneficiaries of municipal services continue to be frustrated by the poor quality of services delivered by municipalities. South African rural communities do not have access to basic services such as water and electricity, while other areas experience infrequent provision of such municipal services (Reitzes, 2009; Nnadozie, 2013). South African municipalities have become the 'development driver' through service delivery, poverty alleviation, infrastructure and economic development (Amis, 1999; Vatala, 2005; Patterson, 2008). Every public institution is created for the provision of public goods and services (Besley \& Ghatak, 2007; Scheye, 2009. However, according to Pretorius and Schurink (2007), post-apartheid South Africa faces foremost challenges in ensuring that municipalities deliver optimum and specialized services to their citizens. Such provision of public goods and services denotes that particular functions must be performed by the municipality in terms of provisions of the relevant mandatory legislation. South African municipalities are still confronted with service delivery challenges as the country transcends the second decade of democracy. Such is apparent by the number of spreading service delivery protests throughout the country that have reached the highest peak during 2012 as compared to other previous years. Service delivery backlogs that exists, particularly in South African municipalities are rooted upon the catastrophe to implement decentralization, mismanagement, corruption, incapacity to deliver to communities and lack of public participation in major municipal decision making (Mbazira, 2013: 251). However authors such as Vatala (2005) and Amis (1999) blame the failure by municipalities to effectively implement service delivery challenges to lack of proper implementation of socio-economic programmes such as the CRDP. These challenges, for the purposes of enhancing municipal service delivery, can be addressed by interventions for ensuring positive impact such as programme management, creating conditions for sustainable service delivery, economic development and public participation (Pretorius \& Schurink, 2007). All if not some of the objectives incorporated in the CRDP can be implemented and executed in local municipalities such as the Greater Giyani, service delivery at a local sphere of government can be accelerated.

\section{Strategic Objectives of the CRDP and the Link to Service Delivery}

The strategic objectives of the CRDP are; agrarian transformation, rural development and land reform (DRDLR, 2009). Proper execution of these strategic objectives and apposite implementation of the CRDP, which would mean satisfying the needs of the intended beneficiaries in Muyexe would augment service delivery in the community and redress the backlogs thereof. Following is a detailed description of each of the CRDP objectives listed above.

\subsection{Strategic objective 1: agrarian transformation}

Agrarian transformation according to the DRDLR (2009) relates to radical change in relation to 'land, livestock, cropping and the community'. According to Seckler (1992) and Pyakuryal and Upreti (2011) agrarian transformation relates to "government-initiated or government-backed redistribution of agricultural land and encompasses an overall redirection of the agrarian system of the country such as land reform measures, training and land consolidation". While agrarian transformation is continuously being compared to land reform, Ben (2007) states that agrarian transformation is mainly concerned with land rights and the distribution thereof. Agrarian transformation is likely to be impossible without government having interfered because this is a complex issue. This is mainly because the redistribution of land includes property rights, which is the sole discretion of government. Agrarian transformation mechanisms if handled properly by government, particularly through the CRDP can accelerate service delivery by ensuring that rural farmers invest heavily on rural farms, and adopt new technologies on regular basis. In the post-apartheid South Africa, there is a need for government to hasten the agrarian transformation process so as to allow for the speedy recovery in terms of service delivery backlogs of the apartheid era.

\subsection{Strategic objective 2: rural development}

For operational purposes the DRDLR (2009), defines rural development as people-centered development whereby communities take charge of their own development initiatives. The CRDP is therefore grounded on community-based active participation whereby the intended beneficiaries of development are 'fully' involved in infrastructural development. According to Kenny (2003) and Nemes (2005), rural development is about seeking to sustain structures of communities with balanced age groups, levels of income and uplifting the socio-economic and cultural standards to uplift the standard of living to rural disadvantaged communities through collective resources of the rural territory itself. The process of 
ensuring augmented service delivery to disadvantaged rural communities in the democratic South Africa can be attained through rural development initiatives such as the CRDP. However, the active involvement of citizens to actively participate and have a choice in the services they receive could hasten to redress the service delivery injustices of the past. According to Pretorius and Schurink (2007), participation by citizens in local affairs is a critical element in ensuring speedy and sustainable services to communities. Service delivery through rural development initiatives such as the CRDP can only be satisfied if there are proper consultative channels created between government and the intended beneficiaries of such initiatives.

\subsection{Strategic objective 3: land reform}

Land according to Zarin and Bujang (1994) is the most basic need particularly for rural dwelling communities. It is the principal form of wealth and the main source of economic and political power (ibid). Deducting from the above connotations, it can be asserted that rural dwellers that were forcibly removed from their land by the apartheid regime remained powerless in all dimensions of their well-beings. This is particularly because they primarily relied on their land for food and other essential endogenous activities, while the government deprived them of basic services. According to Zarin and Bujang (1994), and Barraclough (1999) land reform means an equitable redistribution of land for the benefits of the landless, small farmers, and tenants for agricultural and residential purposes. Land reform specifically deals with 'tenure reform, land redistribution and land restitution (DRDLR, 2009). Land reform can enhance service delivery in the post-apartheid South Africa as it normally attempts a dispersion of wealth and income levels to those who were previously excluded to receiving government services. Land reform could also means that those who were forcibly taken away to remote lands for the purposes of excluding them from receiving services can benefit after such redistribution of land.

\section{Research Design, Approach and Method}

This section of the paper discusses how the study was approached, the research strategy employed, the description of the study area under which the research was conducted and its population. Sampling size and strategy, and the instruments of collecting data are outlined below.

\subsection{Research approach}

There is insufficient literature on CRDP and service delivery challenges in the Greater Giyani municipality and other South African municipalities. As a result a case study approach was adopted for this study. The rationale for adopting this approach is that the research was conducted without sufficient literature and theoretical background on the topic, because the CRDP was recently adopted by government.

\subsection{Research strategy}

Both quantitative and qualitative case study methodology was employed in this empirical study to collect data on CRDP and service delivery in the Muyexe pilot project within the Greater Giyani municipality. Mixed methodologies assist the researcher to capitalize on the best of both strategies. Mixed approaches allow for the use of both inductive and deductive reasoning and make the research results more generalizable (O'leary, 2010: 128). The CRDP implemented in Muyexe is so complex and dynamic and requires for both the descriptive and numeric deductions for the purposes of generating the results for this study.

\subsection{Study area}

Muyexe is situated 40 kilometers northeast of Giyani town, within the jurisdiction of the Greater Giyani municipality in Limpopo province. It is home to an estimated population of 2356, consisting of the poorest of the rural poor. It is one of the most impoverished communities within the municipality and the country as a whole with no immediate job opportunities available. The community of Muyexe is entirely rural situated in the close proximity of the Kruger National Park. The residents of the Muyexe community survive mainly from hunting and farming. Due to the demographics the community is situated, there is no enough rain to support the farming activities. To redress the past injustices and inequalities in terms of service delivery, the South African government launched in 2009 the CRDP as a pilot project in 
Muyexe.

\subsection{Research population}

Muyexe village has an estimated total of 900 households. However, there is no conclusive evidence indicating exactly how many residents institute these households. The Integrated Development Plan (IDP) of the Greater Giyani Municipality draws conclusion that the ward, in which Muyexe is situated, have an equally fair distribution of both males and females. Muyexe consist of approximately 1100 residents, taking in to account that ward 18 has a total population of 4800, which consist of Khakhala village and Gawula village.

\subsection{Sampling strategy and size}

The sample was selected using both the random and purposive sampling strategies. Random sampling strategy is used so that the research findings can be generalized to the entire population. The purposive sampling strategy is used when participants are selected on the basis of prior knowledge and information that can be conferred to the researcher.

The major criterion to use when deciding on sample size is the extent to which the sample is representative of the population, and this can be expressed in terms of probability (Bless, Higson-Smith \& Kagee, 2006: 107). This study randomly selected 100 participants from a pool of high school learners, teachers, youth, the elderly and community leaders from the Muyexe community. A further 5 municipal officials from the Greater Giyani municipality who were directly involved in the CRDP were also selected purposively to participate in the study.

\subsection{Data collection instruments}

In this study, data was gathered using semi-structured questionnaires which comprised of encoded and open-ended questions so as to allow the respondents to further articulate on their responses. Unstructured interviews were also used as a data collection technique in this study.

\section{Research Findings}

From the 100 respondents sampled to participate in this study, only 86 responses were acquired (86\%), while 14 respondents (14\%) did not return the questionnaires. Hence the findings of this study relates to the responses given by 86 respondents.

\subsection{Socio-economic welfare in relation to service delivery}

The researcher wanted to find out from the respondents at Muyexe about the socio-economic status and service delivery prior to the implementation of the CRDP and whether the situation changed after the implementation in 2009. The majority of the respondents (73\%) indicated that the CRDP has not brought any significant change in terms of service delivery, $21 \%$ of the respondents are of the view that CRDP has made some strides in addressing the socio-economic wellbeing and the level of service delivery. $6 \%$ of the respondents were not sure of whether changes visible in the village were part of the CRDP or not. The respondents indicated that, prior to the implementation of the CRDP, Muyexe did not have running water and proper roads and that is still the case after 2009. However, some of the respondents indicated that the CRDP played a role in changing the livelihood of the residents because of the built clinic, the post office and the satellite police station.

Following is a summary of responses from the respondents at Muyexe village on whether the CRDP has brought any socio-economic change in relation to service delivery since implementation. 
Figure 1: Socio-economic welfare in relation to service delivery

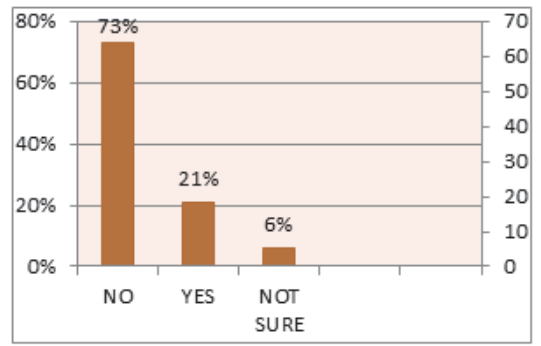

Source: Figure compiled by the researcher

\subsection{Strategic objectives of the CRDP and the link to service delivery}

The strategic objectives of the CRDP are; agrarian transformation, rural development and land reform.

\subsubsection{Strategic objective 1: agrarian transformation}

The researcher wanted to find out from the respondents at Muyexe on whether the CRDP addressed the objective of agrarian transformation in Muyexe village. The majority (47\%) of the respondents showed uncertainty on whether the CRDP has addressed the issue of agrarian transformation, while $32 \%$ of the respondents totally disagreed that the CRDP has not touched on any issue relating to agrarian transformation. Only $21 \%$ of the respondents agreed that the CRDP has addressed agrarian transformation as a strategic objective. A major problem in these responses might be that the CRDP has not specifically stated what agrarian transformation will specifically deal with. On the issue of agrarian transformation, the Grater Giyani Municipality responded that the CRDP ensured the financing of communal gardens and tanks so as to ensure that the land given for agricultural purposes have water. However it was observed that there is no water in the village, therefore the issue of communal garden cannot be a justification of the municipality in failing to properly deal with agrarian transformation.

\subsubsection{Strategic objective 2: Rural development}

According to the Public Service Commission (2009: 4) rural development is multi-dimensional and much broader than poverty alleviation through social programmes and transfers. The multi-dimensionality of development emphasizes that in order for development to take place, many elements, which might be the responsibility of many role players in the targeted rural area, must be in place (ibid).

The researcher wanted to find out from the respondents at Muyexe village if Muyexe is a developed community. Majority of the respondents (97\%) indicated that Muyexe village cannot be regarded as a developed community. While a mere $3 \%$ stated that Muyexe is a developed community. The respondents indicated that without running water and proper roads, the area can never be developed.

One of the respondents "the community cannot be a developed community if money and resources are still used for unnecessary things such as an unequipped sport center and unutilized community center".

Following is a summary of responses from the respondents at Muyexe on whether the CRDP has achieved rural development. 
Figure 2: Rural development

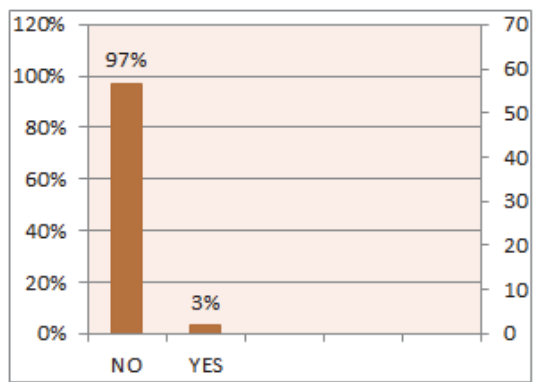

Source: Figure compiled by the researcher

\subsubsection{Strategic objective 3: Land reform}

The Land reform programme encompasses three distinct components, namely restitution, tenure reform, and the redistribution programme (DRDLR, 2009: 16). The question was posed on whether the CRDP has achieved the strategic objective of land reform. The majority (57\%) of the respondents believe that the CRDP has properly dealt with issues of land reform, 34\% of the respondents indicated that the issue of land reform at Muyexe has not been properly attended to. $9 \%$ of the respondents were not sure as to whether the CRDP has addressed land reform issues or not. Some of the respondents' indicated their lack of knowledge with regard to issues confronting land reform. Following is the analysis of responses regarding land reform as indicated by the respondents:

Figure 3: Land Reform

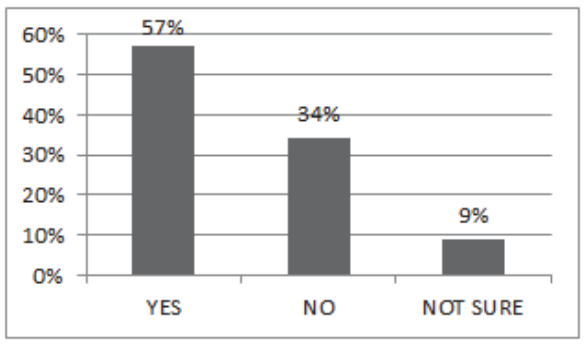

Source: Figure compiled by the researcher

\subsection{The state of roads and water in Muyexe village}

The researcher wanted to find out from the respondents at Muyexe about the state of the roads and water. The state of roads and water in Muyexe is unacceptable. Majority of the respondents (98\%) indicated that water and roads in the village are among the worse services they receive. Only $2 \%$ of the respondents indicated that the state of water and roads was partially satisfying. None (0\%) of the respondents indicated that the state of roads and water was in any way satisfying. There are 22 boreholes in the village that were installed as a plan to address the water backlog in Muyexe village as part of the CRDP. However, it is shocking to learn that only 4 boreholes are operational and have to supply water to the entire village. Below is a summary of the responses in terms of the state of roads and water in Muyexe village. 
Figure 4: The state of roads and water at Muyexe

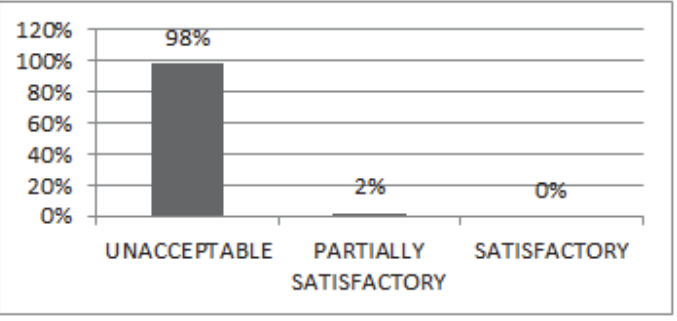

Source: Figure compiled by the researcher

\subsection{Post office}

$100 \%$ residents have access to postal services including post banking. One of the respondents indicated that they welcome the Post Office as one of the major achievements of the CRDP.

One of the respondents said "we don't have to travel to Giyani to deposit our savings as the service can be accessed in the village".

From the information provided above, it can be concluded that all the people in Muyexe village can access postal services that included banking services. The CRDP has successfully dealt with the sub-objective of building a post office.

\subsection{Housing}

$79 \%$ of the respondents have houses while only a mere $21 \%$ do not have access to housing at Muyexe. The findings indicate that housing in Muyexe village is not as a major problem when compared to water and roads. The Nene family at Muyexe village received a four bedroom house courtesy of the Independent Development Trust (IDC), as part of the CRDP. According to the Report of the Select Committee on Land and Environmental Affairs (2012), the original Nene home was a traditional hut and after an exceptionally harsh storm in January 2008 the house was destroyed leaving the family vulnerable. On the basis of the information provided above, it can be concluded that the CRDP has brought change in terms of providing housing.

\subsection{Sanitation}

$84 \%$ of the respondents do not have access to sanitation, while it is only $16 \%$ of the respondents who have access to sanitation. The toilets as indicated in the IDP of the Greater Giyani Municipality have not been built in the village. This is shown by the number of responses where it was stated that sanitation cannot be, if there are no toilets in the households. Sanitation also remains a problem even at school. According to the Report of the Select Committee on Land and Environmental Affairs (2012), due to the lack of a constant water supply, the school could not be provided with flush toilets; hence ventilated pit latrines were erected.

\subsection{Clinics and health facilities}

$100 \%$ of the respondents have access to a clinic and other health facilities. However some respondents stated that the clinic in the village is under-staffed and experiences a constant shortage of medications. Upon conclusion of the Select Committee on Land and Environmental Affairs (2012), visit to the Muyexe hospital the delegation reports that the old visitor's center is still being used as a clinic. Construction of the new hospital building only started in February 2012, with construction being interrupted as a result of no water for construction purposes and the contractor abandoning the project and a new contractor was appointed in July 2012. After interacting further with staff present at the clinic it was ascertained that the clinic does have a dedicated nursing sister and that the doctor visits the area every fortnight. What the delegation found disturbing was that the clinic had run out of basic medicines and that the next delivery was only due in approximately seven days' time. 


\subsection{Rural libraries and internet café.}

$98 \%$ of the respondents do not have access to the library and the internet café, while the other $2 \%$ can access the library and the internet café. Respondents at Muyexe village cannot access a library or any other reading area in their territorial area. Respondents indicated that they used to access the internet at the village. However, there was an internet terminal which was operational in 2011 but has since stopped working for unknown reasons. School learners indicated that they do not have anywhere to study since their home environments are not conducive for studying. According to the Report of the Select Committee on Land and Environmental Affairs (2012), discussions with the school principal revealed that the school still lacks a library. The school principal further explained that in addition to not having a library, the school has still not received any books, with only the foundation phase receiving limited reading materials. The CRDP has dismally failed to address the sub-objective of building a local library and the internet café.

\section{Recommendations}

The following recommendations can be made in order to ensure the achievement of the strategic objectives of the CRDP, so that the socio-economic wellbeing of the local residents can be bettered through the provision of basic services.

- There is a strong necessity for South African municipalities to define and accept clear strategies that would effectively address service delivery through government policy or programmes objectives.

- Socio-economic programmes such as the CRDP, when it is to effectively meet its intended strategic objectives and service delivery, should be subjected to frequent monitoring and evaluation by an external independent body.

- The recipients of municipal services should be proactive in the process of decision making and service delivery affairs.

- Somehow district municipalities as authority bodies for services such as water should be incorporated in complex socio-economic programmes such as the CRDP, as local municipality are in a way proving incompetency.

\section{Conclusion}

Based on this study, it would appear that the Greater Giyani municipality is confronted with challenges in terms of addressing service delivery backlogs through the CRDP within its territory of jurisdiction. Basic services such as water and sanitation have not been properly dealt with as it was intended by the CRDP. However certain positivity on services such as housing and health facilities can be drawn from the programme. The study did not cover every subdomain of the CRDP and service delivery in the Greater Giyani municipality using the Muyexe Pilot Project as a case study. Therefore, the study has opened up a 'crack' for future research in the similar field, particularly on the issue of socio-economic programmes aimed at addressing and enhancing service delivery. The researcher further recommends that similar studies be undertaken in other South African municipalities where the CRDP has been implemented.

\section{References}

Adams, M., Sibanda, S. \& Thomas, G. 1999. 'The institutional arrangements for land reform: The South African case stakeholder workshop on the national land policy', Harare, June 14-15 1999.

Amis, P. 1999. Urban economic growth and poverty reduction. Urban governance, partnership and poverty. Theme paper 2.

Baas, S. 1997. New Trends in Rural Development and Poverty Alleviation: The concept of Participatory Institutional Development. Academic Exchange Conference on Sustainable Agriculture and Sand Control in Gansu Desert Area, China. http://www.fao.org/docrep/013/am162e/am162e00.pdf (Accessed 08 August 2013).

Barraclough, S.L. 1999. Land reform in developing countries: the role of the state and other actors. Discussion paper No. 101, June 1999.

Ben, C. 2007. The land question in South Africa: The challenge of transformation and redistribution. Cape Town: HSRC Press.

Bless C., Higson-Smith C., \& Kagee A. 2006. Fundamentals of social research methods an African perspective (4thEds). Juta \& Co. Ltd: Cape Town.

Greater Giyani Municipality Reviewed Integrated Development Plan 2012/13.

Kenny, M. 2003. Social and economics aspects of policy and planning. http://eprints.nuim.ie/1177/1/MKMod.pdf

Mbazira, C. 2013. Service delivery protests, struggle for rights and the failure of local democracy in South Africa and Uganda: parallels and divergences. South African Journal of Human Resources, 29: 251-275. 
Ministry of Rural Development and Land Reform 2009. The comprehensive rural development Programme framework, http://www.ruraldevelopment.gov.za/phocadownload/Documents/crdp_version1-28july09.pdf (Accessed: 5 February, 2013).

Nemes, G. 2005. Integrated Rural Development, the concept and its operation. KTI/IE Discussion papers 2005/6. Institute of Economics Hungarian Academy of Sciences. http://www.mtakti.hu/doc/dp/dp/mtdp0506.pdf

Ngcamu, S.B. 2013. A qualitative enquiry in to customer care centres: the case of Ethekwini Metropolitan municipality. Journal of Public Administration, 48(1): 22-34.

Nkuna, N.W. \& Nemutanzhela, T.L. 2012. Locating the role of service delivery within powers and functions of local government in South Africa. Journal of Public Administration, 47 (1): 355-368.

Nnadozie, R.C. 2013. Access to basic services in post-apartheid South Africa: What has changed? Measuring on a relative basis. The African statistical journal, 16: 81-103.

O'leary, Z. 2010. The essential guide to doing your research project. London: SAGE Publications: Washington D.C.

Patterson, C. 2008. Local economic development in South Africa. Country report. http://ledna.org/sites/ledna.org/files/country _report_led_in_south_africa_final.pdf. Accessed on 12 February 2014.

Pretorius, D. \& Schurink, W. 2007. Enhancing service delivery in local government: the case of a district municipality. South African Journal of Human Resources Management, 5 (3): 19-29.

Public Service Commission. 2009. An Evaluation of Integration and Coordination in the Integrated Sustainable Rural Development Programme. www.psc.org.za. (Accessed 10 March 2013).

Pyakuryal, K. \& Upreti, B.K. 2011. Land, agriculture and agrarian transformation. Consortium for land research and policy dialogue (COLAR).

Reitzes, M. 2009. The Impact of Democracy on Development: The case of South Africa. Research Report 120. http://cps.org.za/cps\%20pdf/RR120.pdf. (Accesed on 19 February 2014).

Report of the Select Committee on Land and Environmental Affairs. 2012. http://www.parliament.gov.za/live/commonrepository /Processed/20110822/28480_1.doc (Accessed 13 August 2013).

Rungasamy, L. 2011. 'The need for settlement support in land reform projects: focus on sustainable development'. Unpublished Thesis in completion of the study of Maters at the University of South Africa.

Seckler, D. 1992. Agricultural transformation in Africa. Proceedings of the seminar on agricultural transformation in Africa held in Baltimore, Maryland in May 27-29, 1992.

South Africa. 1996. Constitution of the Republic of South Africa, 1996. Pretoria: Government Printers.

Statistics South Africa. 2001. Using the 2001 Census. http://www.statssa.gov.za/publications/CensusHandBook/CensusHandBook.pdf (Accessed on 28 January 2014).

Vatala, S.W. 2005. Synergies between an integrated development plan, a service delivery and budget implementation plan (SDBIP) and other related plans for 2005-2006 fiscal year. Conference Proceedings. Journal of Public Administration: 225-233.

Zarin, H.A. \& Bujang, A.A. 1994. Theory on land reform: An overview. Buletin Ukrur, 5 (1): 9-14.

Besley, T. \& Ghatak, M. 2007. Reforming public service delivery. Journal of African Economies, 16: 127-156. Paper prepared for a plenary session on services in Africa for an AERC meeting held in Johannesburg on 4 December 2005.

Scheye, E. 2009. State-provided service, contracting out, a non-state networks: justice and security as public and private goods and services. Paper commissioned jointly by INCAF and the partnership for democratic governance (PDG). http://www.oecd.org/dac/incaf/43599221.pdf (Accessed on 21 February 2014). 